\title{
Amperometric flow-injection analysis of phenols induced by reactive oxygen species generated under daylight irradiation of titania impregnated with horseradish peroxidase
}

Vanoushe Rahemi ${ }^{a}$, Stanislav Trashin ${ }^{\mathrm{a}}$, Zainab Hafideddine ${ }^{\mathrm{b}, \mathrm{c}}$, Sabine Van Doorslaer ${ }^{\mathrm{b}}$, Vera Meynen ${ }^{\mathrm{d}}$, Lo Gorton ${ }^{\mathrm{e}}$, Karolien De Wael ${ }^{\mathrm{a} *}$

${ }^{a}$ AXES Research Group, University of Antwerp, Groenenborgerlaan 171, 2020 Antwerp, Belgium

${ }^{b}$ BIMEF Laboratory, University of Antwerp, Universiteitsplein 1, B-2610 Wilrijk, Belgium cPPES Research Group, University of Antwerp, Universiteitsplein 1, B-2610 Wilrijk, Belgium ${ }^{\mathrm{d}}$ Laboratory of Adsorption and Catalysis (LADCA), University of Antwerp, Universiteitsplein 1, B-2610 Wilrijk, Belgium

${ }^{\mathrm{e} D e p a r t m e n t}$ of Analytical Chemistry/Biochemistry and Structural Biology, Lund University, PO Box 124, SE-22100 Lund, Sweden

*Corresponding author, E-mail address: karolien.dewael@,uantwerpen.be 


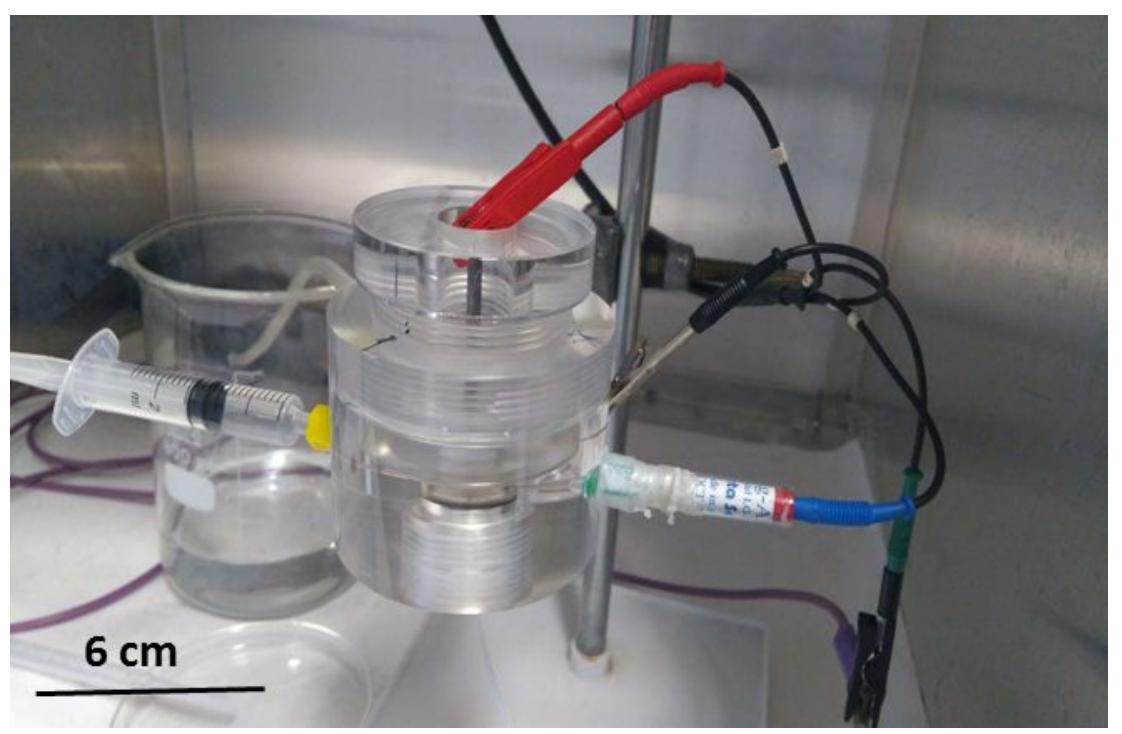

Figure S1. Flow-injection cell.

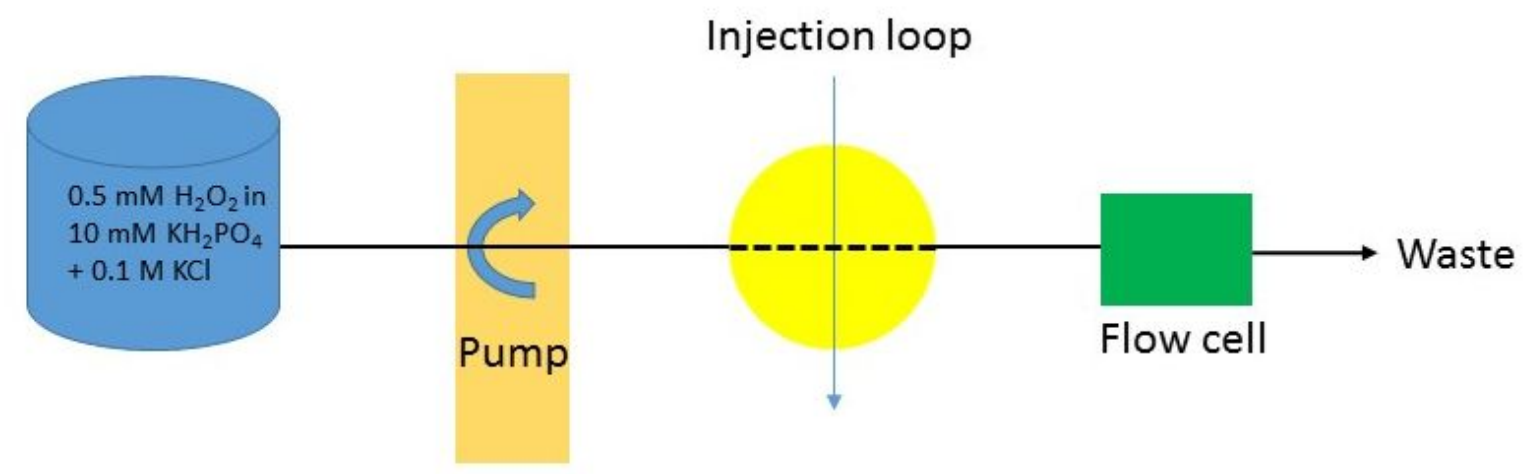

Figure S2. Schematic flow-injection system. 


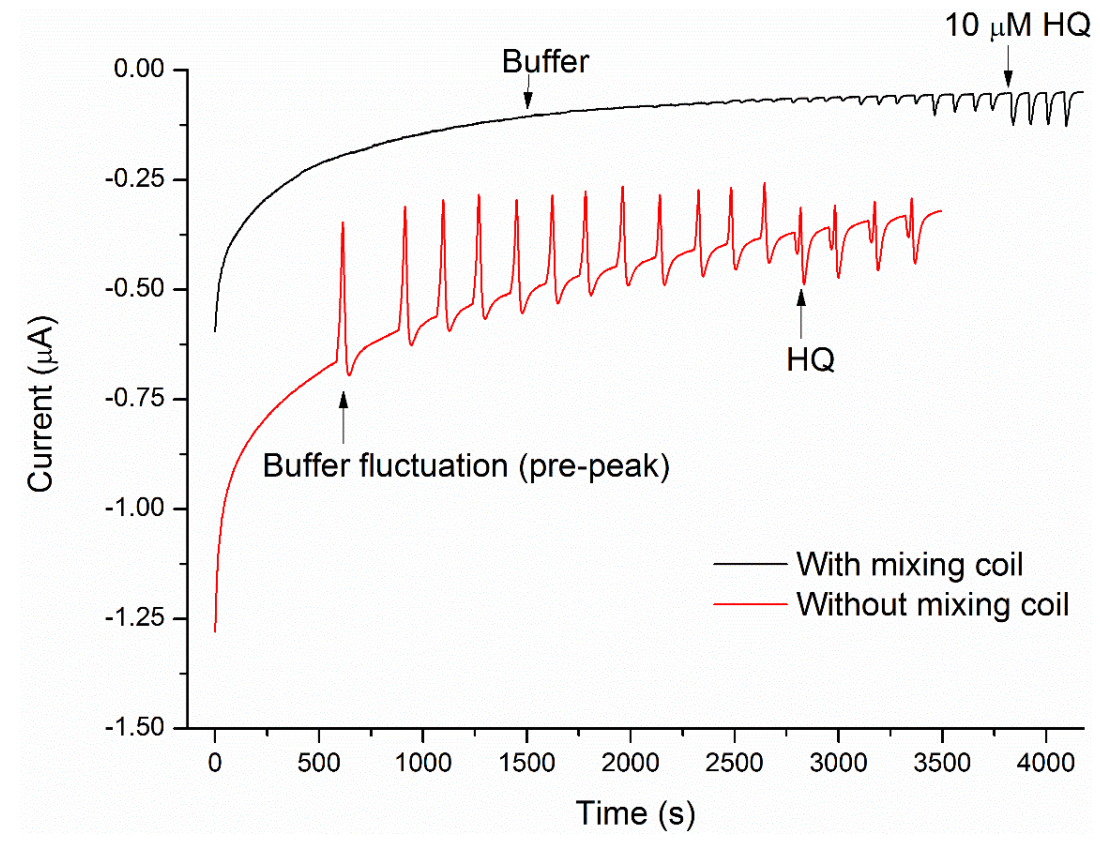

Figure S3. Comparison of background fluctuation upon injection of buffer for two different models with and without mixing coil. 


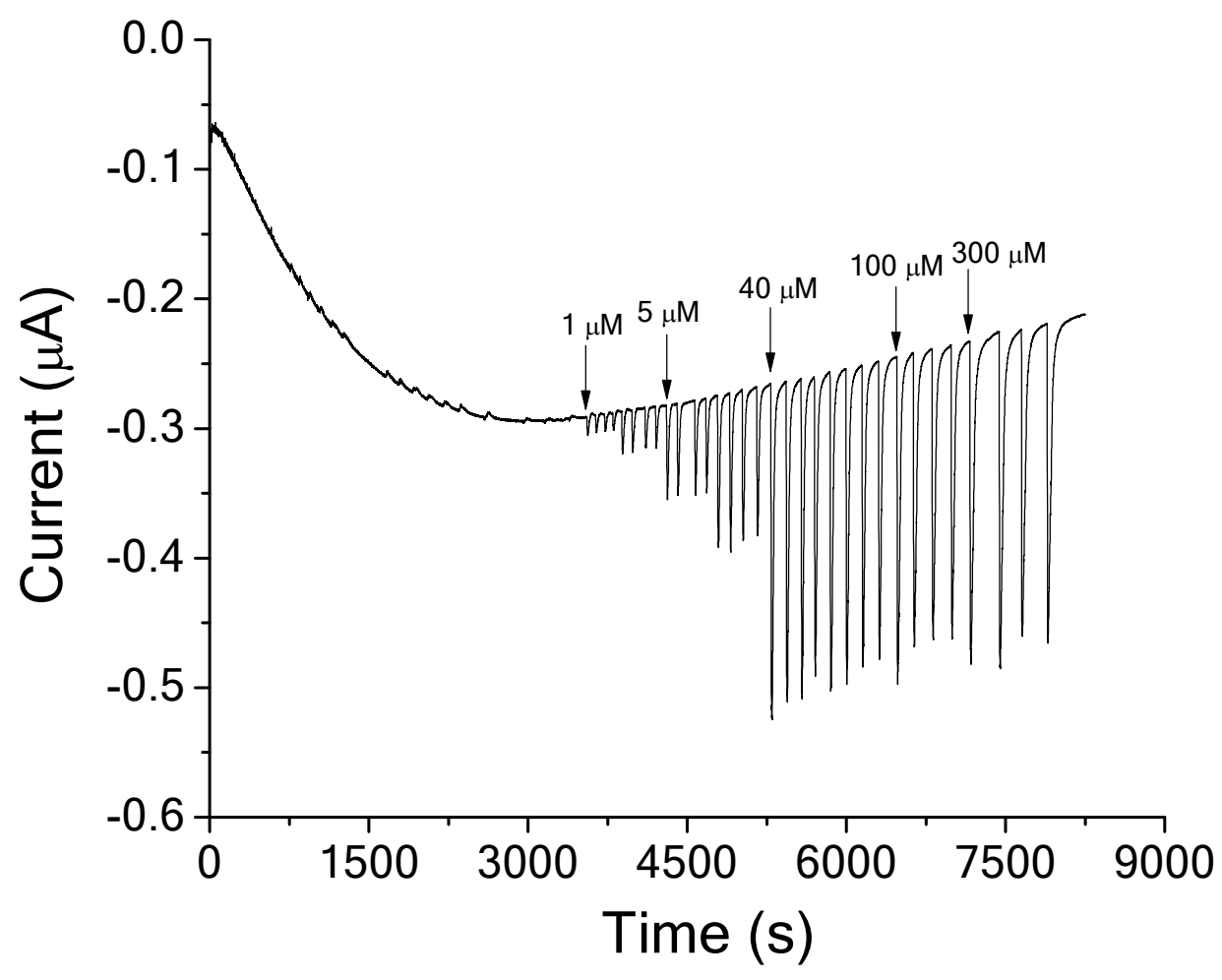

Figure S4. Chronoamperometry curve for different concentration of HQ at Graphite $\mid \mathrm{TiO}_{2}$-HRP in $10 \mathrm{mM} \mathrm{KH_{2 }} \mathrm{PO}_{4}(\mathrm{pH} 7.0)$ containing $0.1 \mathrm{M} \mathrm{KCl}$. Applied potential, $-0.1 \mathrm{~V}$ vs. $\mathrm{Ag} / \mathrm{AgCl}$. Flow rate, $1 \mathrm{~mL} / \mathrm{min}$. 


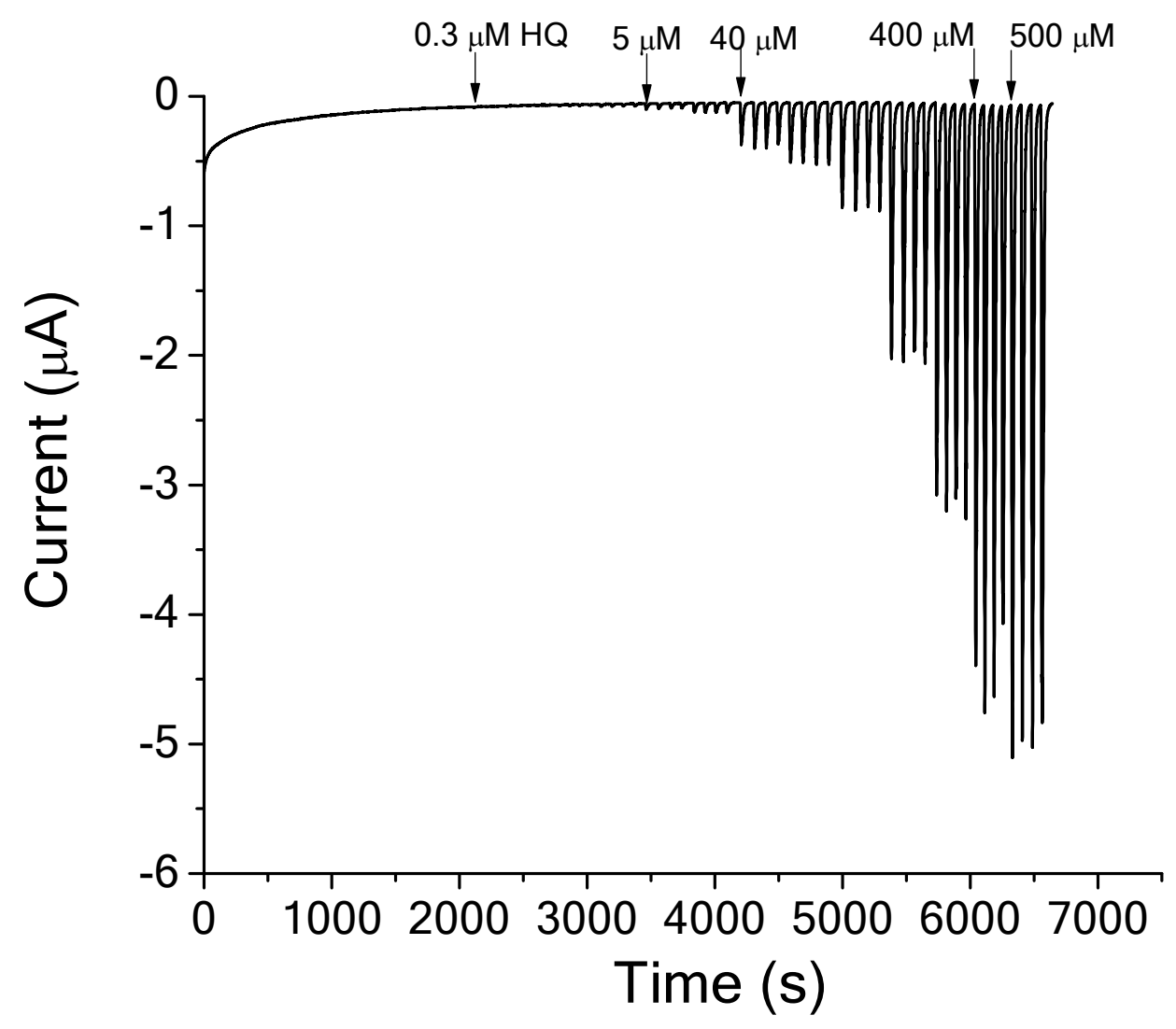

Figure S5. Chronoamperometry curve for different concentration of $\mathrm{HQ}$ at Graphite $\mid \mathrm{TiO}_{2}-\mathrm{HRP}$ in the presence of $1 \mathrm{mM} \mathrm{H}_{2} \mathrm{O}_{2}$ in the carrier buffer $10 \mathrm{mM} \mathrm{KH}_{2} \mathrm{PO}_{4}$ ( $\mathrm{pH}$ 7.0) containing $0.1 \mathrm{M} \mathrm{KCl}$. Applied potential, $-0.1 \mathrm{~V}$ vs. $\mathrm{Ag} / \mathrm{AgCl}$. Flow rate, $1 \mathrm{~mL} / \mathrm{min}$. 


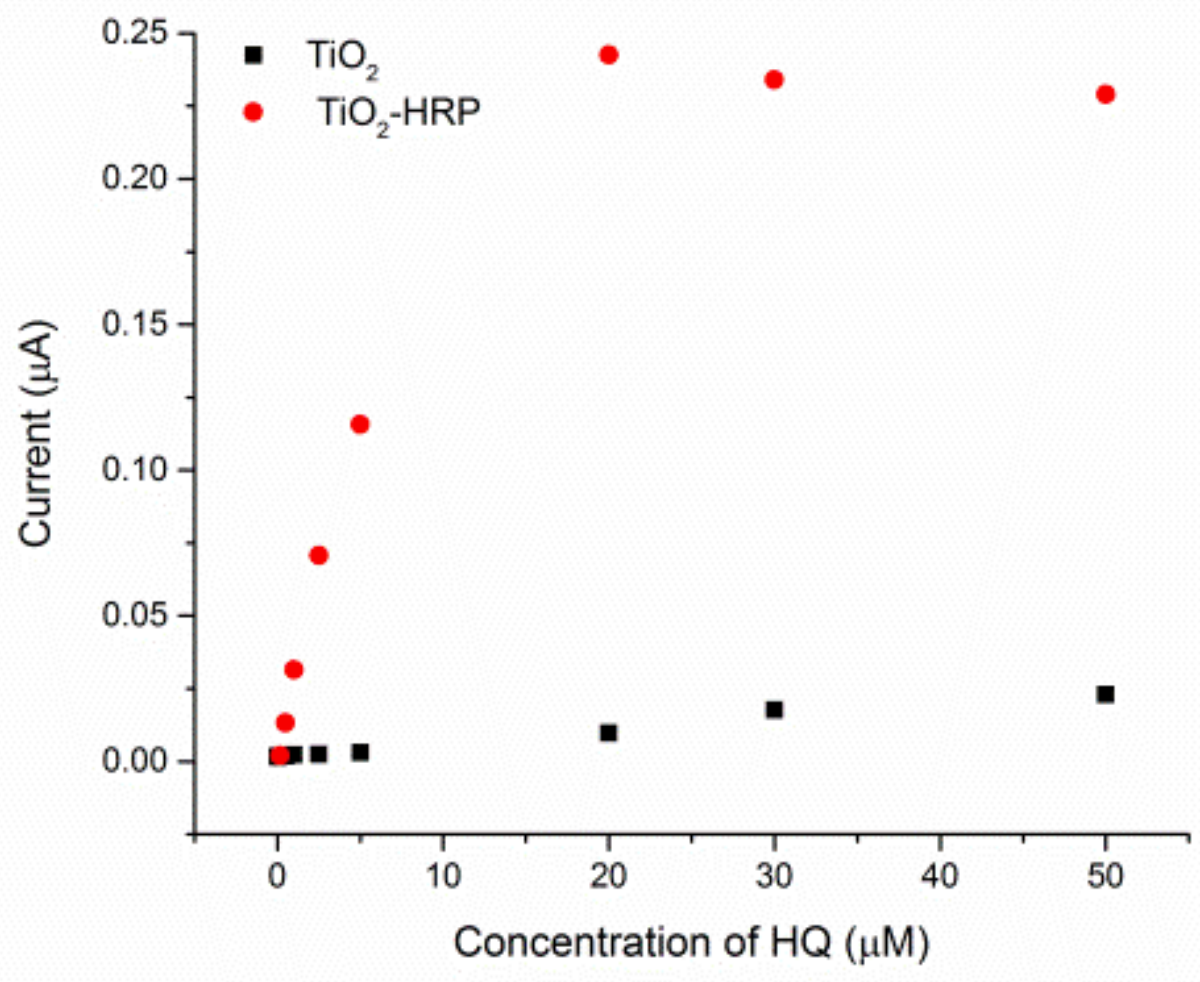

Figure S6. Calibration curve of Graphite|TiO2 and Graphite|TiO2-HRP electrodes in the flow for different concentrations of HQ. Applied potential, $-0.1 \mathrm{~V}$ vs. $\mathrm{Ag} / \mathrm{AgCl}$. Flow rate, $1 \mathrm{~mL} / \mathrm{min}$. 


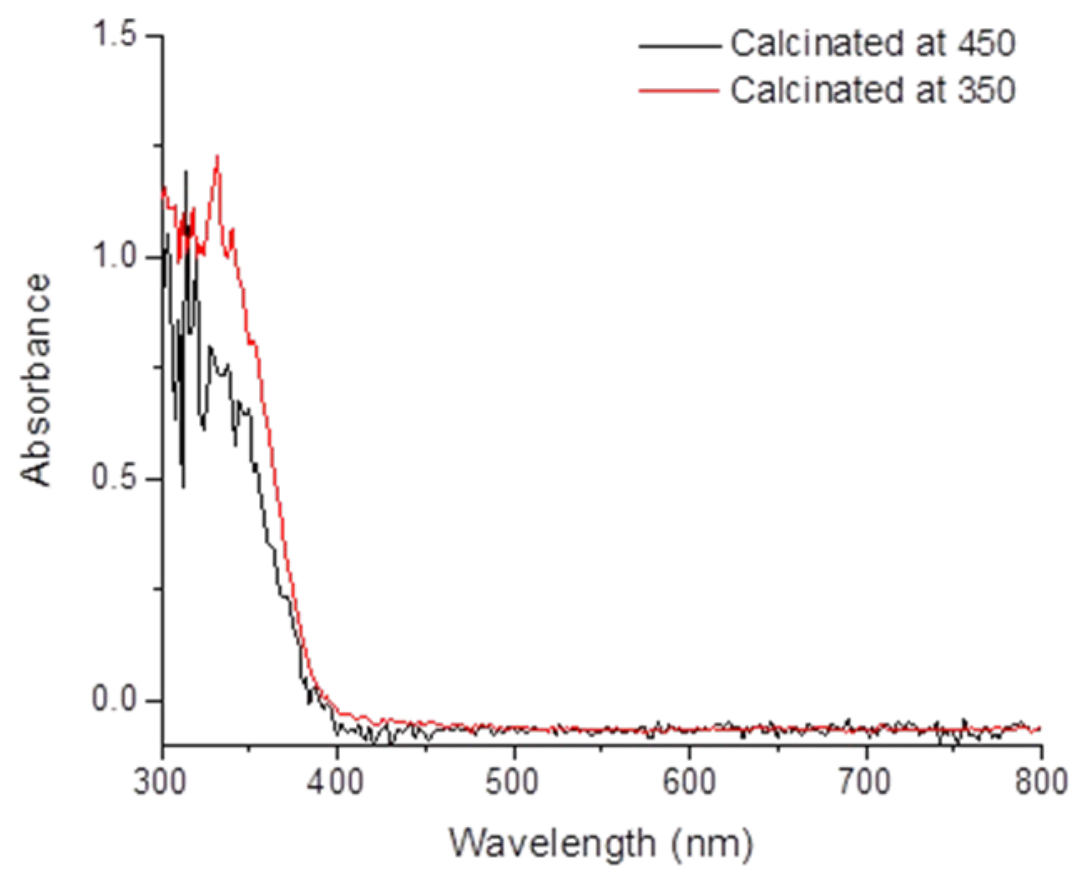

Figure S7. UV-Vis DR spectra of PC500 Millennium $\mathrm{TiO}_{2}$ calcinated at $350^{\circ} \mathrm{C}$ (red) and $450^{\circ} \mathrm{C}$ (black). 


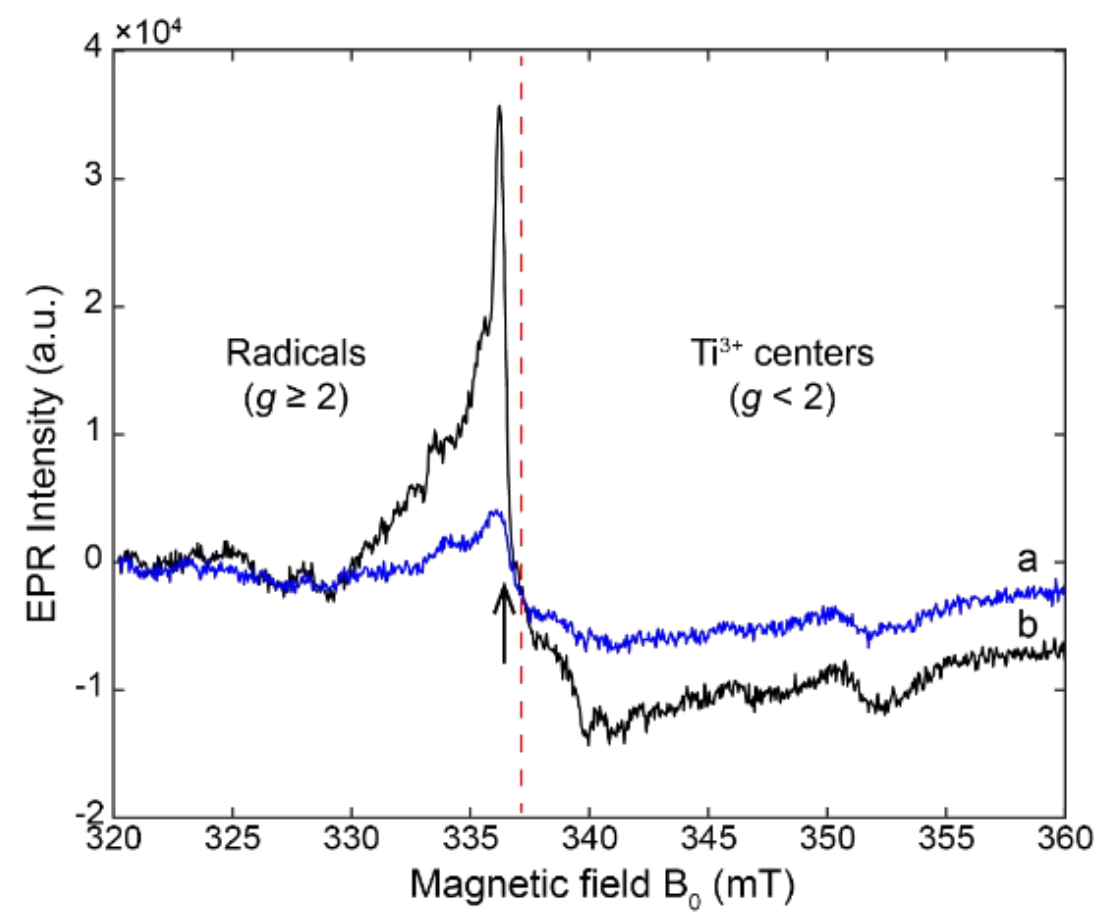

Figure S8. X-band EPR spectrum of (a) PC500 Millenium $\mathrm{TiO}_{2}$ in HEPES buffer $\mathrm{pH}$ 7 and (b) PC500 Millenium $\mathrm{TiO}_{2}$ powder at $10 \mathrm{~K}$. The dashed line marks the $g=2.00$ position, which roughly separates the spectral areas where the contributions of the radicals and $\mathrm{Ti}^{3+}$ can be found. The arrow indicates the radical signal at $g=2.001$. 


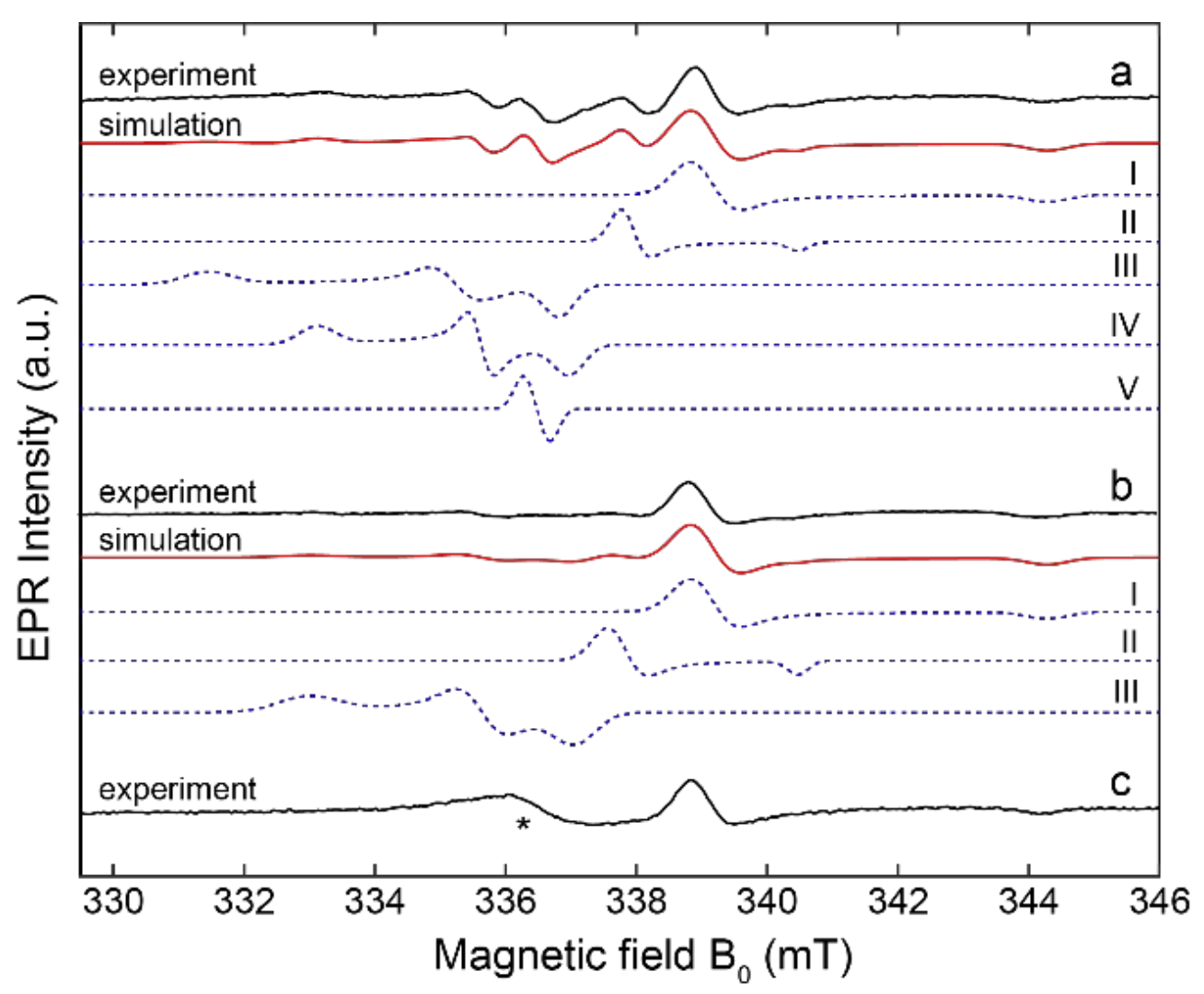

Figure S9. X-band EPR spectrum of the subtraction of the EPR spectrum before illumination from the EPR spectrum during illumination at $532 \mathrm{~nm}$ (light-dark) of a) PC500 Millenium $\mathrm{TiO}_{2}$ powder, b) PC500 Millenium $\mathrm{TiO}_{2}$ powder in HEPES buffer

$\mathrm{pH} 7$ and c) $\mathrm{TiO}_{2}$-HRP powder in HEPES buffer $\mathrm{pH} 7$ measured at $10 \mathrm{~K}$. The corresponding simulated spectra are shown shifted versus the experimental data with the individual components shown as dashed lines. See table S1 for the corresponding $g$ parameters. 


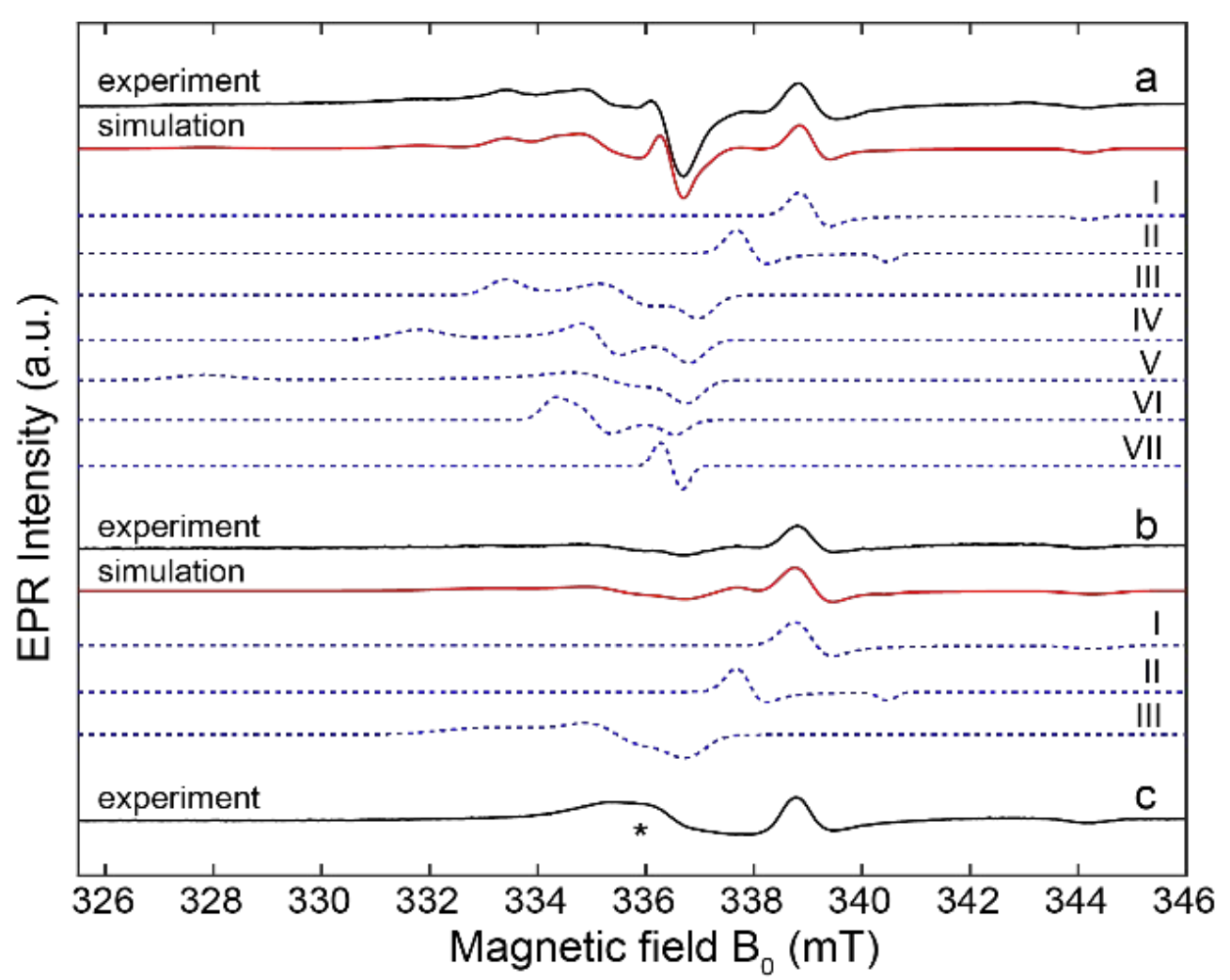

Figure S10. X-band EPR spectrum of the subtraction of the EPR spectrum before illumination from the EPR spectrum during illumination at $447 \mathrm{~nm}$ (light-dark) of a) PC500 Millenium $\mathrm{TiO}_{2}$ powder, b) PC500 Millenium $\mathrm{TiO}_{2}$ powder in HEPES buffer

$\mathrm{pH} 7$ and c) $\mathrm{TiO}_{2}$-HRP powder in HEPES buffer $\mathrm{pH} 7$ measured at $10 \mathrm{~K}$. The corresponding simulated spectra are shown shifted versus the experimental data with the individual components shown as dashed lines. See table S1 for the corresponding $g$ parameters. 
Table S1. Summary of the $g$ values of the species observed on the $\mathrm{PC} 00 \mathrm{TiO}_{2}$ surface. A tentative assignment of the species used for the simulation and their fractional contribution are also given. Species I-II are assigned to $\mathrm{Ti}^{3+}$ centers. Species V (532 $\mathrm{nm})$ and VII $(447 \mathrm{~nm})$ are attributed to $V_{o}^{*}$ centers (localization of electrons at oxygen vacancies) or C-centered radicals. Although the assignment of these species to $V_{o}^{\bullet}$ is still debated in the literature. The $g$ values of species VI are ascribed to $\mathrm{O}_{3}^{-}$. It should be noted that species $\mathrm{V}$ show an unusual high $g_{\mathrm{z}}$ value. Therefore, the assignment of species $\mathrm{V}$ to $\mathrm{O}_{2}^{-}$should be treated as tentative. The high $g_{\mathrm{z}}$ values (2.022-2.034) are typical for $\mathrm{O}_{2}^{-}$(species III-IV), confirming the presence of $\mathrm{O}_{2}^{-}$on the $\mathrm{TiO}_{2}$ surface.

\begin{tabular}{|c|c|c|c|c|c|c|}
\hline & & $g_{z}$ & $g_{y}$ & $g_{x}$ & $\begin{array}{l}\text { Tentative } \\
\text { assignment }\end{array}$ & $\%$ \\
\hline \multicolumn{7}{|c|}{ Illumination at $532 \mathrm{~nm}$} \\
\hline \multirow{5}{*}{$\begin{array}{l}\mathrm{TiO}_{2} \\
\text { powder }\end{array}$} & Species I & $\begin{array}{l}1.9590 \\
\pm 0.0005\end{array}$ & $\begin{array}{l}1.9895 \\
\pm 0.0002\end{array}$ & $\begin{array}{l}1.9895 \\
\pm 0.0002\end{array}$ & $\mathrm{Ti}^{3+}$ & 59 \\
\hline & Species II & $\begin{array}{l}1.9810 \\
\pm 0.0002\end{array}$ & $\begin{array}{l}1.9966 \\
\pm 0.0002\end{array}$ & $\begin{array}{l}1.9966 \\
\pm 0.0002\end{array}$ & $\mathrm{Ti}^{3+}$ & 7 \\
\hline & Species III & $\begin{array}{l}2.0350 \\
\pm 0.0050\end{array}$ & $\begin{array}{l}2.0120 \\
\pm 0.0030\end{array}$ & $\begin{array}{l}2.0025 \\
\pm 0.0010\end{array}$ & $\mathrm{O}_{2}-/ \cdot \mathrm{OOH}$ & 13 \\
\hline & Species IV & $\begin{array}{l}2.0248 \\
\pm 0.0005\end{array}$ & $\begin{array}{l}2.0096 \\
\pm 0.0003\end{array}$ & $\begin{array}{l}2.0015 \\
\pm 0.0010\end{array}$ & $\mathrm{O}_{2}^{-}$ & 19 \\
\hline & Species V & $\begin{array}{l}2.0060 \\
\pm 0.0015\end{array}$ & $\begin{array}{l}2.0045 \\
\pm 0.0005\end{array}$ & $\begin{array}{l}2.0030 \\
\pm 0.0015\end{array}$ & $\begin{array}{l}V_{o}^{\bullet} \text { or C-centered } \\
\text { radical }\end{array}$ & 2 \\
\hline \multirow[t]{3}{*}{$\begin{array}{l}\mathrm{TiO}_{2} \\
\text { suspension }\end{array}$} & Species I & $\begin{array}{l}1.9590 \\
\pm 0.0005\end{array}$ & $\begin{array}{l}1.9895 \\
\pm 0.0002\end{array}$ & $\begin{array}{l}1.9895 \\
\pm 0.0002\end{array}$ & $\mathrm{Ti}^{3+}$ & 76 \\
\hline & Species II & $\begin{array}{l}1.9810 \\
\pm 0.0002\end{array}$ & $\begin{array}{l}1.9966 \\
\pm 0.0002\end{array}$ & $\begin{array}{l}1.9966 \\
\pm 0.0002\end{array}$ & $\mathrm{Ti}^{3+}$ & 4 \\
\hline & Species III & $\begin{array}{l}2.0257 \\
\pm 0.0005\end{array}$ & $\begin{array}{l}2.0096 \\
\pm 0.0003\end{array}$ & $\begin{array}{l}2.0010 \\
\pm 0.0010\end{array}$ & $\mathrm{O}_{2}^{-}$ & 20 \\
\hline \multicolumn{7}{|c|}{ Illumination at $447 \mathrm{~nm}$} \\
\hline \multirow{7}{*}{$\begin{array}{l}\mathrm{TiO}_{2} \\
\text { powder }\end{array}$} & Species I & $\begin{array}{l}1.9590 \\
\pm 0.0005\end{array}$ & $\begin{array}{l}1.9897 \\
\pm 0.0002\end{array}$ & $\begin{array}{l}1.9897 \\
\pm 0.0002\end{array}$ & $\mathrm{Ti}^{3+}$ & 21 \\
\hline & Species II & $\begin{array}{l}1.9810 \\
\pm 0.0002\end{array}$ & $\begin{array}{l}1.9966 \\
\pm 0.0002\end{array}$ & $\begin{array}{l}1.9966 \\
\pm 0.0002\end{array}$ & $\mathrm{Ti}^{3+}$ & 1 \\
\hline & Species III & $\begin{array}{l}2.0230 \\
\pm 0.0010\end{array}$ & $\begin{array}{l}2.0096 \\
\pm 0.0010\end{array}$ & $\begin{array}{l}2.0015 \\
\pm 0.0010\end{array}$ & $\mathrm{O}_{2}^{-}$ & 29 \\
\hline & Species IV & $\begin{array}{l}2.0330 \\
\pm 0.0010\end{array}$ & $\begin{array}{l}2.0124 \\
\pm 0.0010\end{array}$ & $\begin{array}{l}2.0025 \\
\pm 0.0010\end{array}$ & $\mathrm{O}_{2}^{-}$ & 20 \\
\hline & Species V & $\begin{array}{l}2.0580 \\
\pm 0.0050\end{array}$ & $\begin{array}{l}2.0120 \\
\pm 0.0020\end{array}$ & $\begin{array}{l}2.0030 \\
\pm 0.0020\end{array}$ & $\mathrm{O}_{2}^{-}(?)$ & 20 \\
\hline & Species VI & $\begin{array}{l}2.0175 \\
\pm 0.0005\end{array}$ & $\begin{array}{l}2.0130 \\
\pm 0.0010\end{array}$ & $\begin{array}{l}2.0040 \\
\pm 0.0010\end{array}$ & $\mathrm{O}_{3}^{-}$ & 6 \\
\hline & Species VII & $\begin{array}{l}2.0060 \\
\pm 0.0015 \\
\end{array}$ & $\begin{array}{l}2.0045 \\
\pm 0.0005 \\
\end{array}$ & $\begin{array}{l}2.0030 \\
\pm 0.0015 \\
\end{array}$ & $\begin{array}{l}V_{o}^{\bullet} \text { or C-centered } \\
\text { radical }\end{array}$ & 3 \\
\hline \multirow[t]{3}{*}{$\begin{array}{l}\mathrm{TiO}_{2} \\
\text { suspension }\end{array}$} & Species I & $\begin{array}{l}1.9590 \\
\pm 0.0005\end{array}$ & $\begin{array}{l}1.9897 \\
\pm 0.0002\end{array}$ & $\begin{array}{l}1.9897 \\
\pm 0.0002\end{array}$ & $\mathrm{Ti}^{3+}$ & 55 \\
\hline & Species II & $\begin{array}{l}1.9810 \\
\pm 0.0002\end{array}$ & $\begin{array}{l}1.9966 \\
\pm 0.0002\end{array}$ & $\begin{array}{l}1.9966 \\
\pm 0.0002\end{array}$ & $\mathrm{Ti}^{3+}$ & 4 \\
\hline & Species III & $\begin{array}{l}2.0260 \\
\pm 0.0003\end{array}$ & $\begin{array}{l}2.0110 \\
\pm 0.0002\end{array}$ & $\begin{array}{l}2.0030 \\
\pm 0.0002\end{array}$ & $\mathrm{O}_{2}^{-}$ & 41 \\
\hline
\end{tabular}




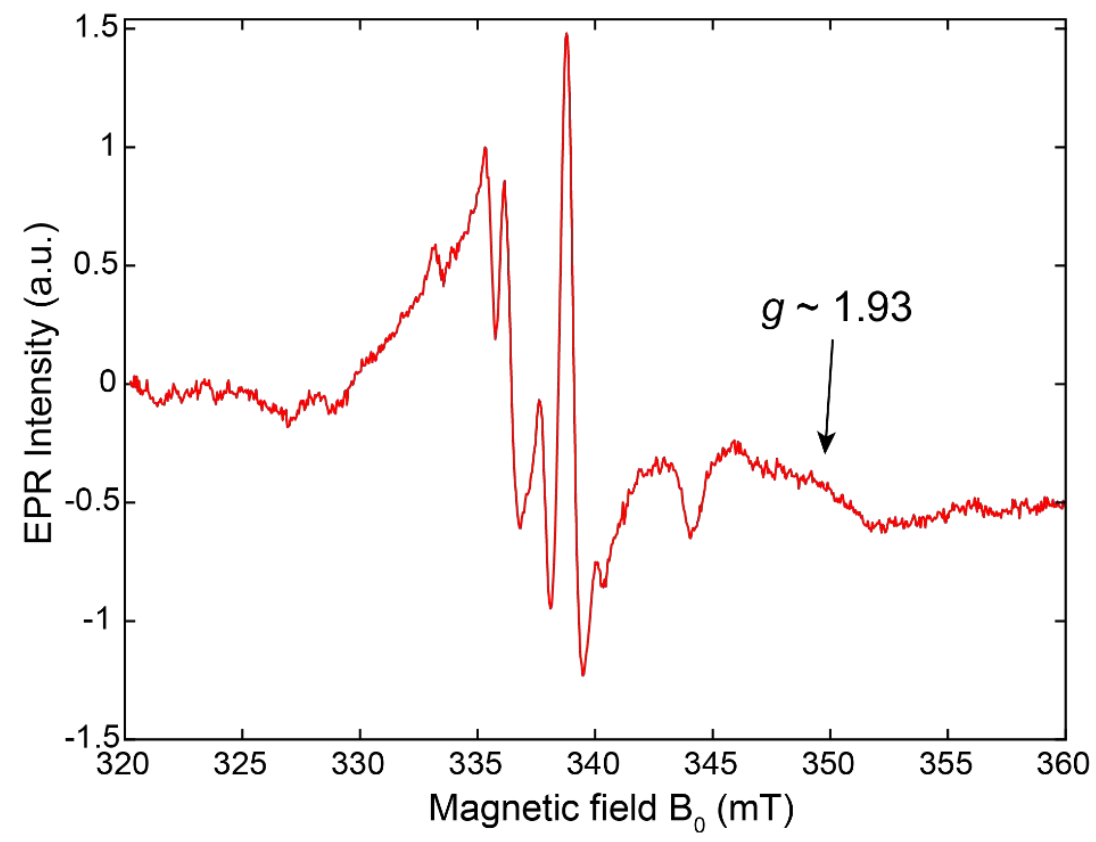

Figure S11. X-band EPR spectrum of PC500 $\mathrm{TiO}_{2}$ powder after 30 minutes of irradiation at $532 \mathrm{~nm}$ measured at $10 \mathrm{~K}$. The broad $g \sim 1.93$ signal is indicated.

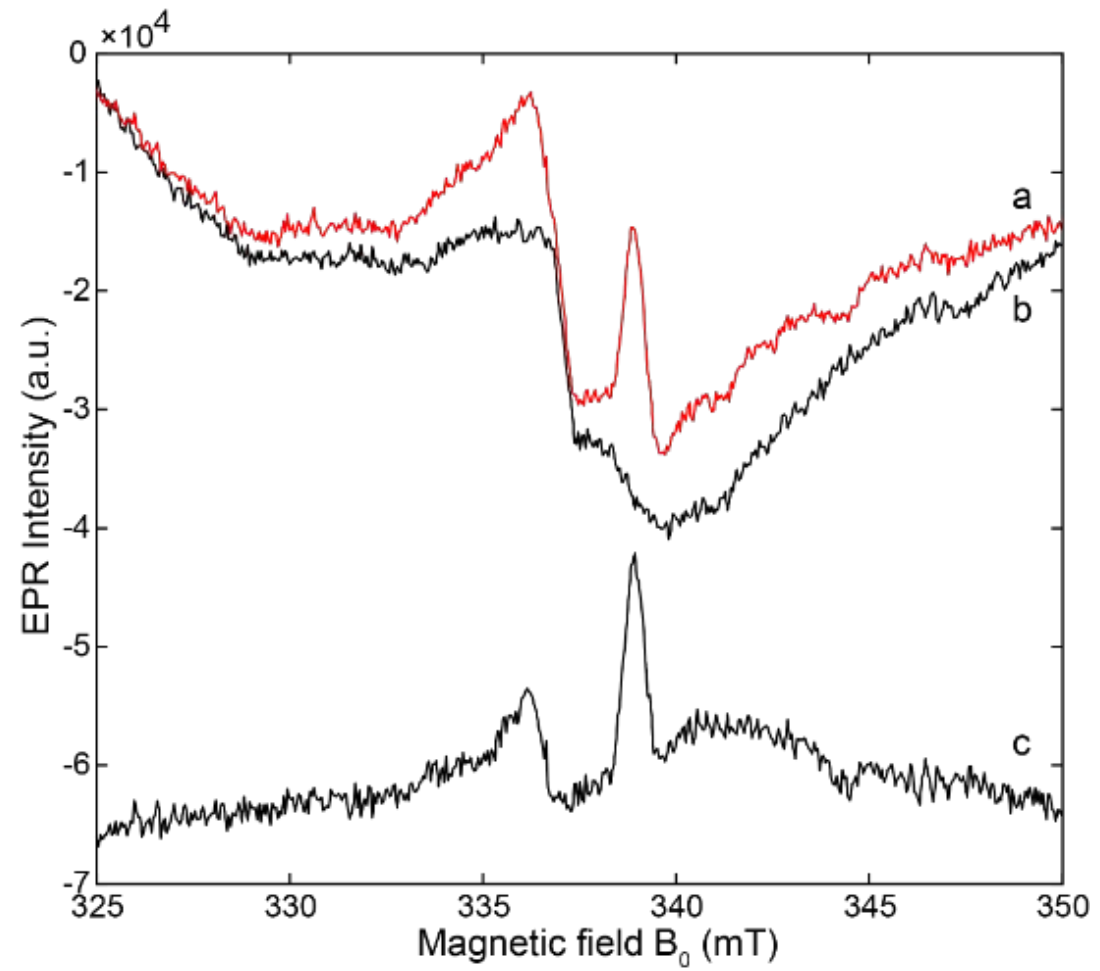

Figure S12. X-band EPR spectrum of a) $\mathrm{TiO}_{2}$-HRP powder in HEPES buffer $\mathrm{pH} 7$ and 10 $\mu \mathrm{M}$ HQ before illumination and $\mathrm{b}$ ) after illumination at $532 \mathrm{~nm}$ measured at $10 \mathrm{~K}$. The subtraction (light-dark) is shown in c). 

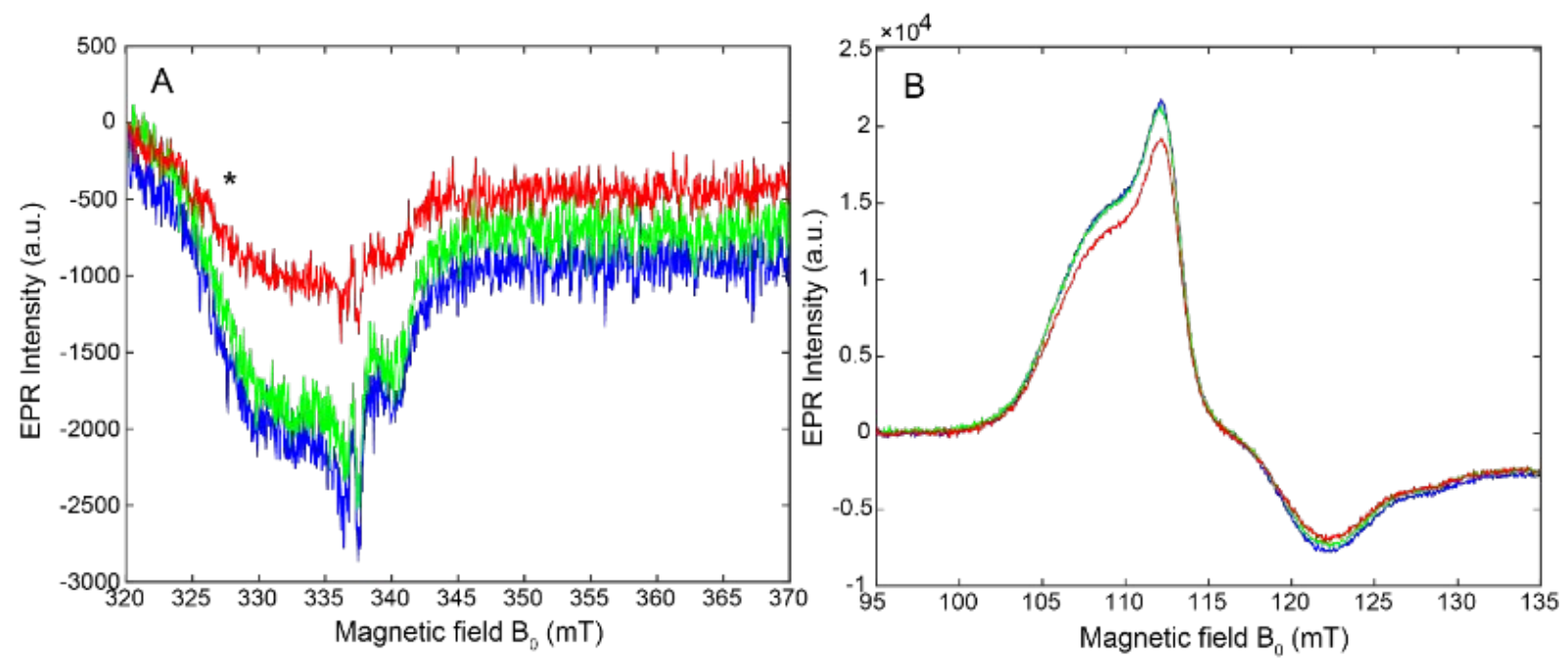

Figure S13. A) The high-field area and B) the low-field area of the X-band EPR spectra of $\mathrm{HRP}-\mathrm{SiO}_{2}$ powder (blue), during illumination at $532 \mathrm{~nm}$ (red) and after switching the laser off for 15 minutes (green) measured at $10 \mathrm{~K}$. *indicates the contribution of a $\mathrm{Cu}^{2+}$ background signal.

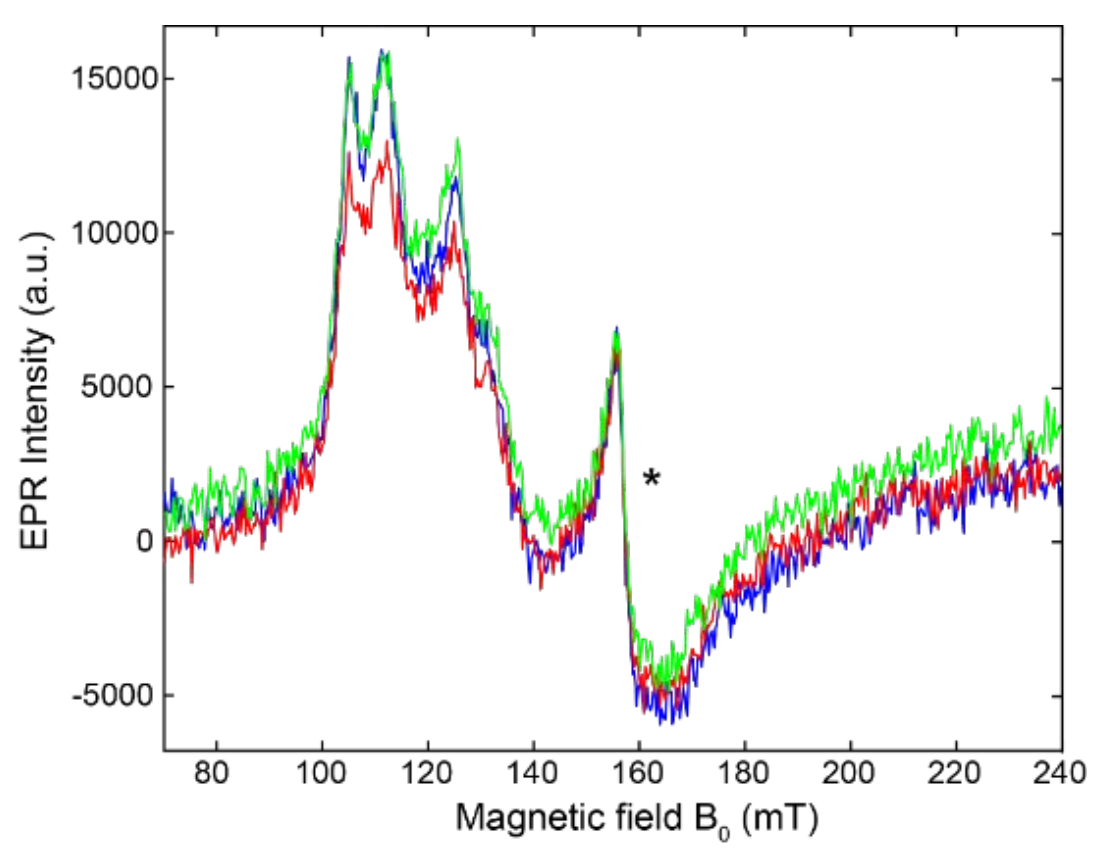

Figure S14. The low-field area of the X-band EPR spectra of $\mathrm{HRP}^{-\mathrm{TiO}_{2}}$ in $\mathrm{HEPES}$ buffer $\mathrm{pH} 7$ (blue), during illumination at $532 \mathrm{~nm}$ (red) and after switching the laser off for 15 minutes (green) measured at $10 \mathrm{~K}$. *indicates the non-heme $\mathrm{Fe}^{3+}$ signal which is also present in the blank $\mathrm{TiO}_{2}$ batch. 


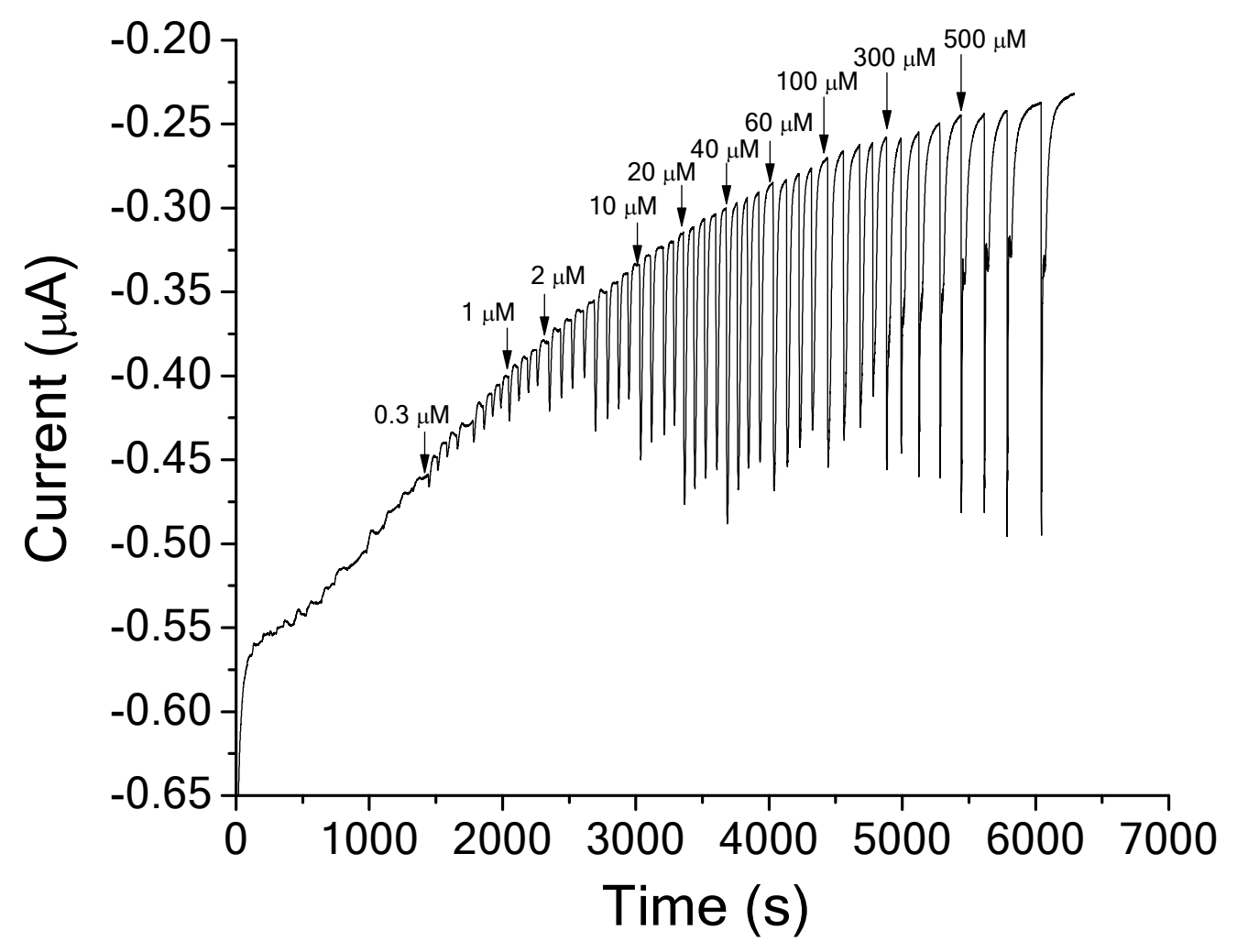

Figure S15. Chronoamperometry curve for different concentration of 4-aminophenol (4-AP) at Graphite $\mid \mathrm{TiO}_{2}-\mathrm{HRP}$ in $10 \mathrm{mM} \mathrm{KH}_{2} \mathrm{PO}_{4}(\mathrm{pH} 7.0)$ containing $0.1 \mathrm{M} \mathrm{KCl}$. Applied potential, $-0.1 \mathrm{~V}$ vs. $\mathrm{Ag} / \mathrm{AgCl}$. Flow rate, $1 \mathrm{~mL} / \mathrm{min}$.

Table S2. 4-AP recovery value for river water samples. The values presented as average \pm SD $(n=4)$.

\begin{tabular}{lccc}
\hline Spiked $(\mu \mathrm{M})$ & Current measured $(\mu \mathrm{A})$ & Concentration found $^{\mathrm{a}}(\mu \mathrm{M})$ & Recovery $(\%)^{\circ}$ \\
\hline 0.050 & $0.018 \pm 0.001$ & $0.054 \pm 0.006$ & $106 \pm 11$ \\
0.100 & $0.029 \pm 0.003$ & $0.096 \pm 0.012$ & $96 \pm 11$ \\
0.200 & $0.038 \pm 0.003$ & $0.130 \pm 0.012$ & $65 \pm 6$ \\
\hline
\end{tabular}

${ }^{a}$ calculated from a calibration curve obtained in deionized water at the same sensor: $y=0.2629 x$ $+0.004\left(\mathrm{R}^{2}=0.97\right)$, where $\mathrm{y}$ is current in $\mu \mathrm{A}$ and $\mathrm{x}$ is concentration in $\mu \mathrm{M}$. 